ENTREPRENEURSHIP AND SUSTAINABILITY ISSUES

ISSN 2345-0282 (online) http://jssidoi.org/jesi/

2020 Volume 7 Number 4 (June)

http://doi.org/10.9770/jesi.2020.7.4(29)
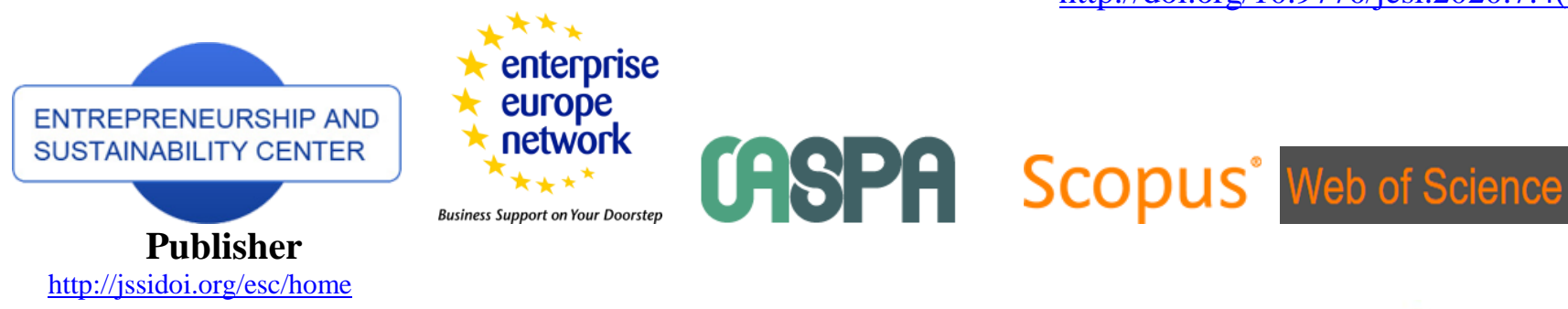

http://jssidoi.org/esc/home

\title{
IMPACT OF INNOVATIVE ACTIVITY OF ORGANIZATIONS ON THE DEVELOMENT OF PHARMACEUTICAL INDUSTRY: A CASE STUDY
}

\author{
Natalia Leonidovna Borscheva ${ }^{1}$, Yulia Vyacheslavovna Fedorova ${ }^{2}$, Marina Ivanovna Glukhova ${ }^{3}$, \\ Guzal Ilgizovna Islamova ${ }^{4}$
}

1,2,3,4 I.M. Sechenov First Moscow State Medical University (Sechenovskiy Univertsity), 8/2 Trubetskaya Street, Moscow, Russia

E-mails: ${ }^{1}$ borscheva_nl@mail.ru,${ }^{2}$ praskovia68@yandex.ru,${ }^{3}$ miss4@yandex.ru,

Received 18 October 2019; accepted 9 April 2020; published 30 June 2020

\begin{abstract}
The article proposes a new methodological approach to the study and evaluation of external factors affecting innovation activity. External factors were estimated, a correlation model was built, and key factors affecting innovation activity and susceptibility to innovation of Russian companies were identified. A regression model reflecting the dependence of the level of innovation activity of Russian companies on changes in environmental factors in the dynamics from 2006 to 2016 was constructed. The study was conducted on the basis of statistical data on the development of the pharmaceutical industry as one of the high-tech industries of the Russian industry. The study confirmed and measured the relationship between the macro factors of development of the Russian pharmaceutical industry and the volume of its production. This study is an occasion to discuss and further study the development of sound recommendations to change or improve the state industrial policy. Directions of further researches are connected with a deeper study of the causes of interrelation of volume of output and macroeconomic factors, as well as with the assessment of the temporal distribution of the macroeconomic consequences of purposeful influence on the magnitude of the factors considered.
\end{abstract}

Keywords: management; innovative activity; innovative development; model; external environment factors; pharmaceutical industry

Reference to this paper should be made as follows: Borscheva, N.L., Fedorova, Y.V., Glukhova, M.I., Islamova, G.I. 2020. Impact of innovative activity of organizations on the develoment of pharmaceutical industry: a case study. Entrepreneurship and Sustainability Issues, 7(4), 3001-3015. https://doi.org/10.9770/jesi.2020.7.4(29)

JEL Classifications: O11, O31, O32

\section{Introduction}

Today in Russia there is a low innovative activity of enterprises and organizations. The diagram (fig. 1) shows the indicators of innovative activity of Russian companies in dynamics. Innovative activity of organizations is the share of organizations that carried out technological, organizational, marketing innovations in the reporting year, in the total number of organizations surveyed. Innovative activity in scientific works is determined by researchers 


\section{ENTREPRENEURSHIP AND SUSTAINABILITY ISSUES}

ISSN 2345-0282 (online) http://jssidoi.org/jesi/

2020 Volume 7 Number 4 (June)

http://doi.org/10.9770/jesi.2020.7.4(29)

on the basis of unit $\mathrm{R} \& \mathrm{~d}$ costs in relation to the volume of products sold and on the basis of the share of $\mathrm{R} \& \mathrm{~d}$ costs in the revenue of companies (Smolina E.S. et al 2019, Brem A. 2016).

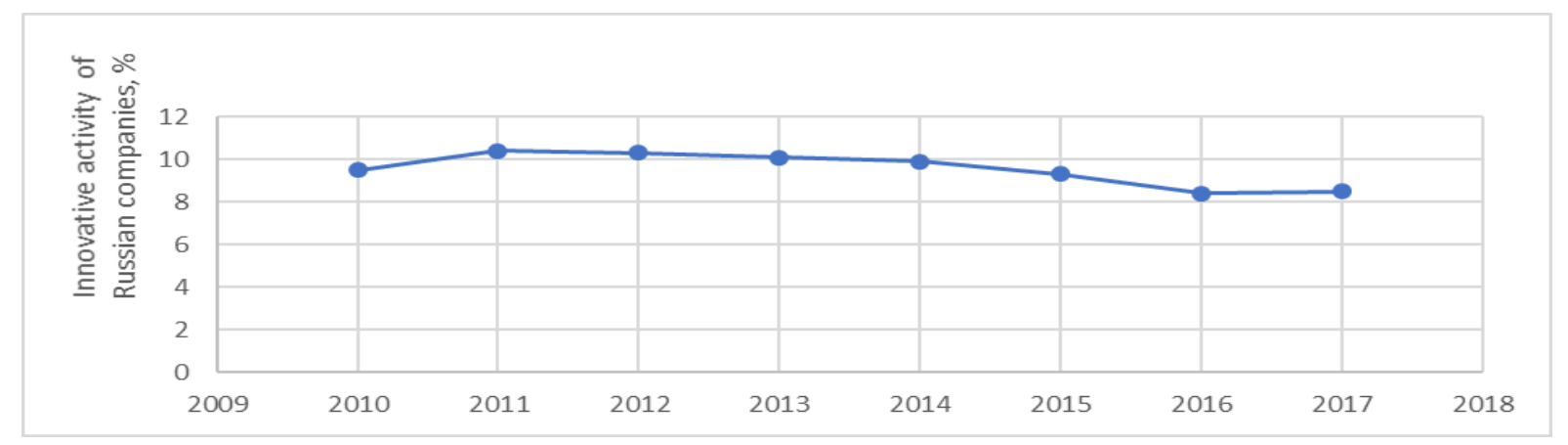

Fig.1. Innovative activity of Russian companies in dynamics from 2010 to 2017

Source: Russian Federal State Statistics Service

To increase innovation activity and susceptibility to innovation of Russian organizations, the authors of this study propose to assess the impact of external conditions, to determine the factors that have the greatest and least impact on innovative organizations. Using the data of the research "Global innovation index -2018", as well as the official data of the Federal state statistics service of the Russian Federation and the results of statistical surveys of innovation activities obtained by the research Institute "Higher school of Economics", the authors conducted their own study of the influence of external factors on the development of innovation in Russia. The study was conducted on the basis of statistical data of the pharmaceutical industry, which is one of the highly innovative sectors of the Russian economy.

It should be noted that this study has a number of limitations. Firstly, the collected data on external factors were obtained from various studies, the frequency of which varies, and some are completely single. Such a situation could create some distortion in the studied dependencies. Second, some of the measured variables, for example, the index of efficiency of activity of bodies of state power, corruption perception index, the index of political stability index of political rights, are subjective, and may not reflect the actual situation.

Today the Russian pharmaceutical industry is one of the high-tech industries of economy. The share of innovatively active pharmaceutical entities and organizations constitutes 31,3\% (IFPMA 2017). The Russian pharmacotherapeutical market is one of the most dynamic and fast-growing markets in the world. The final sale price of pharmaceutical products increases annually. According to the forecasts shown in "The concept of longterm social and economic development of the Russian Federation for the period till 2020", the volume of the Russian pharmaceutical market by 2020 will reach 1,5 trillion rubles. However, today the pharmaceutical industry is characterized by a set of unresolved problems and draws more and more attention of experts and government officials. Production of the "branded" generics is common for the entities. Therefore, the final consumer overpays for trade names of the medicines often obsolete and having lost their clinical efficiency. Product portfolios of domestic pharmaceutical producers for the most part consist of low-profitable generics that does not allow producers to allocate more than $1-2 \%$ of the revenue for scientific researches and developments, wherein currently, domestic producers provide only $20 \%$ of necessary substances for pharmaceutical industry. Today the Russian pharmaceutical industry is unable to provide the Russian market with main nomenclature of modern medicines produced entirely on the Russian territory.

The world's largest pharmaceutical market by total sales for more than 20 years remains the United States Sales of medicines per capita in this country more than twice the average sales for the countries of the Organization for 


\section{ENTREPRENEURSHIP AND SUSTAINABILITY ISSUES}

ISSN 2345-0282 (online) http://jssidoi.org/jesi/

2020 Volume 7 Number 4 (June)

http://doi.org/10.9770/jesi.2020.7.4(29)

economic cooperation and development (OECD, OECD) (Health at a Glance 2015). (Pharmaceutical spending 2016). In 2015, the per capita cost of the industry's products in the United States amounted to $\$ 1,162$ (OECD average - \$515) (Pharmaceutical spending 2016). Compared to other countries, the United States prescribes and sells much more medicines in terms of both the number of packages and per capita costs. Moreover, in the United States, the total cost of health care is far ahead of all other developed countries, what explains the large size of the US pharmaceutical market, and determines the opportunities, including innovative, companies from the United States (Niu, J. et al.2019).

The cost of pharmaceutical innovation has reached gigantic proportions - for example, the launch of one new drug on the market in 2014-15 was costing more than 1.3 billion us dollars (direct costs), and the amount of capitalized costs per drug reached 2.5 billion dollars (whereas in the mid-1990s it was about 360 million dollars, and in the 1970s - less than \$ 200 million ) (Ding M. et al. 2014), (DiMasi J. et al. 2003), (DiMasi J. et al. 2016). However, the direct costs of developing one drug are significantly lower and, according to various estimates, not more than half of the indicated cost (DiMasi J. et al. 2016). Since only one of the many drugs being developed and undergoing clinical trials is successful, the total cost of one drug that has become successful consists of the costs of all other studies. The most important place in pharmaceutical innovative developments is occupied by the US Share of the US in the total volume of world innovative developments for 2016 is $26.4 \%$, and in the total volume of pharmaceutical (including biotechnology) - more than 43\% (Global R\&D Funding Forecast 2016).

\section{Materials and methods}

The external environment provides opportunities for any company to organize its successful activities, as well as the necessary resources to maintain the company's potential. The management of the enterprise needs to control the relationship with external factors, as the company is in close interaction with the external environment, both in the production process and in the process of implementation. There are four main characteristics of the external environment.

First, it is a difficulty. The complexity is due to the number of factors affecting the company. Complexity is an element that characterizes the number of environmental factors and the relationship between these factors. The external environment in terms of complexity can be classified as: homogeneous (simple environment) in which there is not a large number (3-4) similar elements of the external environment affecting the organization, and heterogeneous (complex environment), which contains a large number of heterogeneous elements of the external environment of the company, affecting the organization, and are in close interaction with the company.

A homogeneous environment is more predictable for the manager, which simplifies the process of development and management decision-making. The multiplicity and uniqueness of the factors influencing the activities of the organization is the number of significant objects, as well as their close connection with the activities of the organization. The difficulty lies in the fact that the company has to deal with a wide range of factors, the close connection with the activities of which is not always certain, but is of great importance.

Secondly, it is the interconnectedness. The content of the element of interconnectedness is that the impact of some factors has an impact on the changes of others, and there is a degree of these changes. Interconnectedness of factors is the basic characteristic that determines the relationship between the company's activities and the impact of the external environment. Dependence or independence shows the density of the relationship of the company's activities with the external environment. Isolation is also an indicator of the relationship between structures in the external environment. An isolated environment is peculiar by an unstable structure of communication with the subjects, or their absolute absence. 


\section{ENTREPRENEURSHIP AND SUSTAINABILITY ISSUES}

ISSN 2345-0282 (online) http://jssidoi.org/jesi/

2020 Volume 7 Number 4 (June)

http://doi.org/10.9770/jesi.2020.7.4(29)

The company in its activities, as a rule, is always in interaction with customers, partners, suppliers, consumers, competitors. At the same time, any company in its activities strives for maximum independence.

Third, uncertainty. The essence of the uncertainty element is the degree of ownership of information about changes in the environment, as well as the degree of confidence in the reliability and accuracy of the information received. A situation in which the company does not have sufficient information on the status and trends of external factors increases the risk of unsatisfactory performance of the company as a whole.

Fourth, variability. By its nature, the element of variability is to determine the mobility of environmental factors. For the successful functioning of any company, the most important thing is the stability of relations with the external environment. In situations where there is a high level of complexity and mobility of the environment, then to solve these problems, management needs to rely on information obtained from different sources, as well as be able to change their own priorities. In some cases, to make successful decisions, it is important to be able to revise the formed system of values and culture of the company.

In the context of dynamic changes in environmental factors, it is necessary to carry out regular monitoring and analysis of new strategies and approaches. This knowledge will allow to make adequate and balanced decisions. It should be marked that today there is no single established classification of factors affecting the innovation of staff. Today, there are several opinions about what factors have an impact on work motivation.

Several specialists classify factors only on the basis of classification on the basis of belonging to external and internal, direct and indirect. Factors with indirect effects are more complex than those with direct effects. For our research, indirect impact factors are of greater scientific interest.

Factors of indirect influence of the external environment are classified into five groups, while external factors experts include: political and legal (changes in the regulatory framework and the political situation in the country), economic (general state of the economy, the state of the labor market, capital, changes in working conditions), technological (changes in technological standards, the development of technologies in the field of production and business processes), social (social standards, ethnic norms, social values, social and psychological factors), international (international migration, etc.).

The impact of political factors on the innovation activities of the company and on the efficiency of the use of labor resources is manifested in the following: the definition of rules and norms of profit taxation, the establishment of tax benefits, the establishment of subsidized trade duties, requirements for the practice of hiring labor, control of tariffs, the establishment of wage rates, etc.

For companies operating internationally, political stability plays an important role. The indicators characterizing this type of factors include: government performance index, corruption perception index, political stability index, political rights index, number of Federal targeted programs to support innovation, infrastructure for innovation development (special economic zones). The political rights index applies to assess categories such as electoral process, political pluralism, government participation and functioning.

The presence of Federal targeted programs to support innovation characterizes the government's interest in the development of innovation, which in turn allows us to give an answer about the need and the possibility of investing in this area. Increasingly, this indicator (the presence of Federal targeted programs to support innovation) is important for assessing the development of education in R \& D. Since the dynamics of this indicator allows us to estimate the potential demand for it. 


\section{ENTREPRENEURSHIP AND SUSTAINABILITY ISSUES}

ISSN 2345-0282 (online) http://jssidoi.org/jesi/

2020 Volume 7 Number 4 (June)

http://doi.org/10.9770/jesi.2020.7.4(29)

The dynamics of the infrastructure indicator for the development of innovations also indicates the demand from the state and government for activities in the field of innovation, including in the pharmaceutical market.

The lack of funds in the pharmaceutical market inevitably affects all sectors, including the amount of spending on $\mathrm{R} \& \mathrm{D}$ and social support. In turn, all these factors, due to their close relationship with economic entities, have a negative impact on the development of these entities.

In our article, as a working hypothesis, we assume that if the interest of the state and public spending increases, then the innovative activity of the pharmaceutical market subjects will stabilize at a certain acceptable level, which will allow starting the innovative activity of the industry.

This hypothesis is confirmed by Fig. 1 and Fig. 2, as these figures show, with the growth of budget expenditures, innovation activity stabilizes at a certain acceptable level, this level can become a starting position, some potential for future growth of innovation activity.

In our paper we assume, that that external factors can have both positive and negative impact on innovation activity. The indicators that characterize these type of factors (economic factors) include: the global competitiveness index, investment in intellectual property, investment in fixed capital, R \& D costs, the share of organizations that used global information networks from the total number of surveyed.

The global competitiveness index includes 12 components of competitiveness: infrastructure, macroeconomic stability, health care, primary education, higher education, vocational training, product market efficiency, labor market efficiency, financial market complexity, technological readiness, business complexity, innovation (The Global Competitiveness Report 2018)

Investment in intellectual property is one of the key factors of the investment market. For effective development modern production requires a developed market of intellectual goods, in other words, investment in intellectual capital.

Investments in intellectual property are called intellectual investments. Intellectual investments are made in the form of acquisition:

- Exclusive property rights through the purchase of patents, licenses, industrial designs, trademarks;

- Information services: one-time (consulting, expertise, recommendations, etc.) and permanent (use of knowledge and experience of scientists and practitioners from the contractual system of cooperation);

- Scientific and technical products (design and estimate documentation, programs, techniques, know-how) on various material media (printed materials, video), as well as the implementation of research activities.

Investments in the human factor, that is, the cost of education, training and retraining, training, health protection of employees at the expense of state enterprises are considered intellectual investments. The state carries out intellectual investments in order to increase the intellectual potential of society. Consumers of intellectual investment of the state are citizens. Private intellectual investments are made in the publication of scientific, reference books, research works, popular science and art works.

Investments in fixed capital are investments aimed at the acquisition, development or expansion of fixed assets, which are indispensable and one of the most expensive tools in the production of innovative products. The impact of this factor on the development of human resources is of great value, because the sphere of innovation cannot function without high-quality perfect equipment. The effectiveness of the staff of an innovative organization depends on the capital intensity, and the capital intensity on the volume of investments in fixed assets.

$\mathrm{R} \& \mathrm{D}$ expenditure is a comprehensive indicator of the total expenditure incurred on research and development work. 
The degree of involvement of organizations in global information networks indirectly indicates the level of information development, the level of access to modern software and the possibility of obtaining relevant data in the field of scientific knowledge, in the field of factors affecting the innovative activity of the company. The indicator of expenditure on education at all levels, and especially its dynamics, shows the government's interest in improving the level of education and training of highly qualified personnel necessary for the development of innovation (Voloshin A. et al.2018, Kayl I.I. 2018, Bogoviz A. 2018, Bogoviz A. 2019, Bogoviz A. 2020, Chashchin V.V. 2013, Crespi G. 2018).

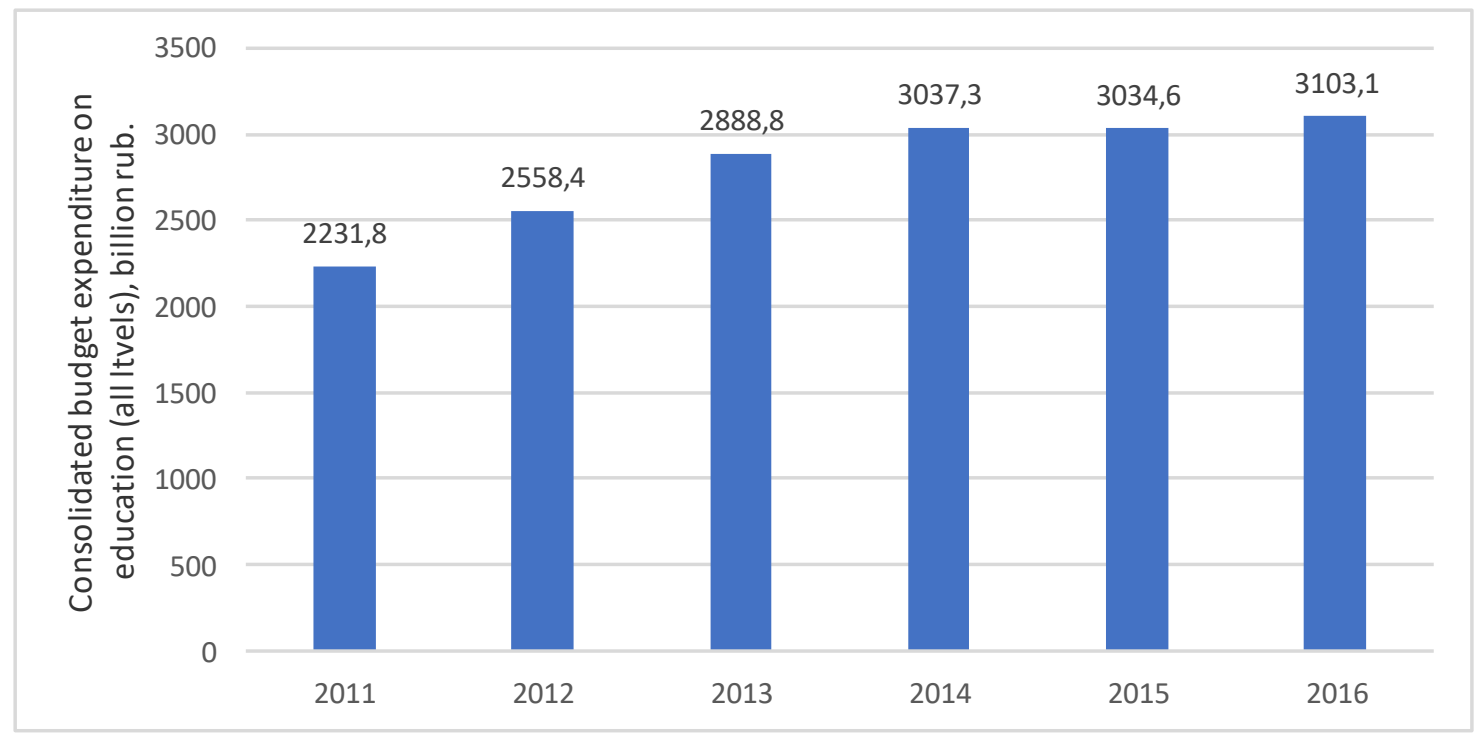

Fig.2. Expenditures of the consolidated budget of the Russian Federation for education (all levels) Source: Russian Federal State Statistics Service

The indicator of public expenditure on education complements the previous indicator and shows the share of expenditure on education in the GDP structure and, accordingly, shows the trend of state policy in training and development of the economy as a whole.

Technological factors are also of great importance. It is important to take into account the interpretation of the term "technology", since its meaning is too broad, including processes of production activities, methods of production activities and techniques of production activities. The introduction of technological innovations has an impact on the efficiency of innovative production, as well as on the speed and methods of collecting and processing information.

Currently, the speed of technology change is very high. Among the main major innovations of the technological field, which have received mass distribution, we can distinguish computer technology, laser development, microwave technology, semiconductor technology, integrated communication lines, robotics, satellite communications, nuclear power, synthetic fuel, as well as food, genetic engineering, etc.

For the effective development of an innovative enterprise, it is necessary to provide a rapid response to the development of a new generation. The indicators characterizing this type of factors include: global innovation index, innovative activity of organizations, the share of organizations engaged in technological innovation in the total number of surveyed organizations, the share of organizations engaged in management innovation, the cost of 


\section{ENTREPRENEURSHIP AND SUSTAINABILITY ISSUES}

ISSN 2345-0282 (online) http://jssidoi.org/jesi/

2020 Volume 7 Number 4 (June)

http://doi.org/10.9770/jesi.2020.7.4(29)

technological innovation, the number of patents granted for industrial designs, the number of shipped innovative products of its own production, developed advanced production technologies.

The index of innovative activity of the organizations is the characteristic of innovative activity in a complex containing information on susceptibility to innovations, degree of intensity of the realized actions directed on transformation of innovations, ability to providing the applied methods, rationality of technological process of innovations. Innovative activity demonstrates readiness to modernize the main components of the innovation system: knowledge, technological equipment, informatively and communication technologies. In addition, innovation activity shows susceptibility to innovation.

The share of organizations engaged in technological innovations in the total number of surveyed organizations shows the degree of development of innovative activity in the total volume of the business community. The indicator of the number of granted patents for industrial designs characterizes the development of the sphere of innovation and the level of availability and involvement of research personnel, as well as this indicator indirectly indicates the capital intensity of the innovation process. The indicator of the developed advanced production technologies allows to estimate efficiency of the organization of innovative production in a complex. And also is an indirect indicator that characterizes the efficiency of the use of labor resources in innovation.

Each organization operates in at least one cultural environment. As a result, the company is affected by various sociocultural factors, as well as customs, values and attitudes.

Socio-demographic factors have a special impact on the staff of innovative organizations. Such factors include: the level of employment, level of unemployment, the number of personnel involved in $\mathrm{R} \& \mathrm{~d}$, business units in organizations engaged in technological innovations, the release from postgraduate study with thesis, the level of economic activity of the population, the size of the minimum wage, the population with incomes below the subsistence minimum, morbidity of population occupational injuries, the duration of life of the population, distribution of total cash income and characteristics of differentiation of cash income of the population (including 20 percent of the population), population change (increase/decrease) for the year, the human development index, etc. (Atatsi E.A. 2016, Barney, J.B 1998).

The level of employment characterizes the activity of the population in the economic environment. Also, this indicator is an indicator of the level of economically active population in terms of age. In other words, in the study of environmental factors affecting the personnel of an innovative enterprise, this indicator can be estimate as an indicator of labor potential.

The unemployment rate indicates the level of economic development in the country, high unemployment is characterized by a slump. Accordingly, in this case, the volume of investment in innovation can also be abridged, which will subsequently affect the efficiency of innovation in General.

The number of personnel engaged in R \& D indicates the involvement of staff in research activities. The study of this indicator was performed in the dynamics, as well as in relation to the indicators of production of $\mathrm{R} \& \mathrm{D}$, indicators of $\mathrm{R} \& \mathrm{~d}$ costs and education costs. The indicator of graduation from graduate school with thesis defense characterizes the dynamics of the personnel market required for the development of innovation. The size of the minimum wage characterizes the provision of the population with money, and, consequently, purchasing power.

The indicator of morbidity is important in the study of the labor potential of innovation. 


\section{ENTREPRENEURSHIP AND SUSTAINABILITY ISSUES}

ISSN 2345-0282 (online) http://jssidoi.org/jesi/

2020 Volume 7 Number 4 (June)

http://doi.org/10.9770/jesi.2020.7.4(29)

Life expectancy is important not only to determine the work potential, but also to determine the need and appropriateness of investment in staff education.

Enterprises operating in the international market face a higher level of complexity. This fact is due to the unique factors that characterize each country individually: culture, economy, quality and quantity of labor resources, regulatory framework, political stability, level of education, level of technological development, etc.

The international factors influencing the labor resources of the innovative company include: international migration, participation of organizations in joint international innovation projects, the share of national presence in the international market of high-tech products (export of high-tech products from Russia) in \% of the world volume of exports of high-tech products, technical achievements (rights to patents, R \& D results, know-how, technology transfer agreements, purchase of innovative equipment) acquired abroad by Russian organizations, carrying out technological innovations, new Russian technologies (technical achievements), transferred to foreign organizations, the volume of exports of innovative goods and services, changes in the ruble to the dollar at the end of the year.

The factor of international migration characterizes the mobility of the population, enhancement or decrease due to migration. Undoubtedly, the inflow of highly qualified and educated people is positive for R \& D purposes.

The index of participation of organizations in joint international innovation projects) shows the level of activity of enterprises in the field of R \& D, and accordingly the level of training of domestic staff and their readiness to work in joint research projects.

The share of the national presence in the international market of high-tech products demonstrates the level of innovative development of the country's economy in general.

Technical achievements acquired abroad by Russian organizations engaged in technological innovation, shows the degree of interest of Russian organizations in the development of innovation and the use of experience of foreign partners.

The number of new Russian technologies (technical achievements) transferred to foreign organizations characterizes the success and efficiency of domestic R \& D enterprises. It should be noted that the value of this indicator should exceed the value of the indicator demonstrating the acquisition of foreign technical achievements. In this case, it will be possible to talk about the effectiveness of the innovation process in the economy in general.

Changes in the ruble exchange rate to the dollar at the end of the year-this indicator in the crisis situation in the economy is one of the most relevant. Since in recent years, the ruble against world currencies has undergone significant changes. Currently, the currency still has an occasional character that has a strong influence on innovation activities of relevance to international contracts.

The analysis of external factors needs conduct on an ongoing basis, as it accumulates information that allows an assessment of the current situation. Analysis of the external environment is the process by which the developers of strategic innovation direction in the company keep under control external to the organization moments to qualify threats and opportunities.

The analysis of the external environment contains:

- economic impact study,

- study of the impact of legal regulation and management, 


\section{ENTREPRENEURSHIP AND SUSTAINABILITY ISSUES}

ISSN 2345-0282 (online) http://jssidoi.org/jesi/

2020 Volume 7 Number 4 (June)

http://doi.org/10.9770/jesi.2020.7.4(29)

- study of political processes,

- study of the natural environment and resources,

- research of social and cultural component of society,

- research of scientific and technological development of society, infrastructure, etc.

Qualitative analysis of the external environment can help to obtain meaningful results. Eventually of timely carrying out of such analysis the organization receives:

- time to predict probabilities,

- time to draw up an intention in case of unexpected events,

- time to develop an early warning system for probable hazards,

- time to develop strategies that have all the chances to turn the former dangers into all sorts of profitable opportunities.

Research scheme:

1. The external factors influencing the innovative activity of pharmaceutical organizations are determined.

2. Selected parameters for evaluation of external factors on sotsialno demographic. economic. political, international. technological direction and the resulting indicator.

3. The key external factors are revealed with the help of correlation matrix.

4. The regression model is constructed on the indicators evaluating external factors. The model was checked for adequacy using Fisher's criterion.

5. A possible scenario affecting the innovative activity of organizations of the pharmaceutical industry of changing external factors has been developed.

\section{Results and discussion}

The objective of this research is identification of external environment factors influencing development of the entities of pharmaceutical industry for the evolvement of strategic directions for further development. Detection of the external factors influencing the development of the pharmaceutical entities is an important problem, as questions of import substitution under the conditions of trade and financial restrictions and high volatility of imported items in light of ruble exchange rate fluctuations require short-term prioritization of directions. Correlation and regression analysis has been applied to determine key macro factors influencing development of the entities in pharmaceutical industry under macroeconomic environment. Its task consisted in estimating the extent of influence of external environment factors to increase the production of major pharmaceutical groups. In the course of this research, the political, economic, social and demographic, technology, international factors influencing the development of pharmaceutical production were identified.

On the whole, about 82 macro-factors have been counted.

The correlation analysis revealed the closest relationship of the resulting indicator (Production of medicines on the major pharmaceutical group) with three external factors (x1, x2, x3). presented in table 1. During the correlation analysis, a large number of external factors (82 factors) were used in the dynamics from 2006 to 2016. (The following is an explanation: The greatest pair correlation between them and a resultant indicator criterion was defined for selection of macro-factors for further research).

The indicator "Production of medicines on major pharmacotherapeutic groups" characterizing the size of the Russian pharmaceutical market has been chosen as resultants. During execution of analysis, some methodological assumptions significant for interpretation were considered. So, the correlation and regression analysis was carried out at the undisplaced level because of the short duration of temporary ranks and due to the need of empirical confirmation of a hypothesis of availability of interrelation between factors and a resultant indicator for further researches. The greatest pair correlation between them and a resultant indicator criterion was defined for selection 
of macro-factors for further research. The constructed correlation model has revealed close connection of a resultant indicator with such factors as "Costs for technological, marketing and organizational innovations" (coefficient of correlation of $r=0,89)$, "An average monthly nominal accrued payroll on an industry" $(r=0,97)$, "Share of the pharmaceutical entities and organizations participating in joint (including foreign) projects on accomplishment of research and development " $(\mathrm{r}=-0,87)$. Statistical data for creation of the regression model shown in table 1 (Gorodnikova, N. et al. 2017), (Healthcare in Russia 2017).

\section{Comments to the table are presented below the table 1.}

Table 1. Statistical data for creation of regression model

\begin{tabular}{|c|c|c|c|c|c|}
\hline $\begin{array}{c}\text { S. } \\
\text { No }\end{array}$ & Time period & $\begin{array}{c}\text { Production of } \\
\text { medicines on the } \\
\text { major } \\
\text { pharmacotherapeutic } \\
\text { groups, billion rub } \\
(\mathrm{y})\end{array}$ & $\begin{array}{c}\text { Costs for } \\
\text { technological, } \\
\text { marketing and } \\
\text { organization } \\
\text { innovations, mln } \\
\text { rub., } \\
(\mathrm{x} 1)\end{array}$ & $\begin{array}{c}\text { An average } \\
\text { monthly nominal } \\
\text { accrued payroll in } \\
\text { an industry, } \\
\text { thousand rub., } \\
\text { (x2) }\end{array}$ & $\begin{array}{c}\text { Share of pharmaceutical } \\
\text { entities and organizations } \\
\text { participating in joint } \\
\text { (including foreign) projects on } \\
\text { accomplishment of research } \\
\text { and development, } \% \text { (x3) }\end{array}$ \\
\hline 1 & 2006 & 57,86 & 870,90 & 10,23 & 17,80 \\
\hline 2 & 2007 & 63,12 & 1024,20 & 13,80 & 17,60 \\
\hline 3 & 2008 & 74,785 & 1084,6 & 17,02 & 17,70 \\
\hline 4 & 2009 & 95,193 & 1228 & 18,651 & 17,50 \\
\hline 5 & 2010 & 130,065 & 1784 & 21,563 & 10,00 \\
\hline 6 & 2011 & 144,327 & 2381 & 25,62 & 10,60 \\
\hline 7 & 2012 & 169,230 & 5025,5 & 30,436 & 12,80 \\
\hline 8 & 2013 & 188,690 & 4345,7 & 35,046 & 12,60 \\
\hline 9 & 2014 & 195,065 & 4640 & 39,087 & 8,5 \\
\hline 10 & 2015 & 237,626 & 5312,3 & 42,348 & 8,2 \\
\hline 11 & 2016 & 298,823 & 5411,6 & 46,609 & $-0,87$ \\
\hline 12 & Coefficient of & & 0,89 & 0,97 & \\
\hline
\end{tabular}

Source: Russian Federal State Statistics Service

With the help of correlation analysis, we check the assumptions that external factors have a great influence on the development of the pharmaceutical industry in Russia.

As the next hypothesis, we assume that with the growth of average wages in the industry, which is usually associated with attracting highly qualified personnel, and with the growth of marketing, technological and organizational costs, which are mainly due to the introduction of new production technologies and management technologies, the production of medicines increases, therefore, the highly innovative pharmaceutical industry develops. Since the access of budget funds to joint and foreign pharmaceutical organizations is limited, with the growth of joint participation and participation in foreign projects, the production of medicines is reduced.

This hypothesis is confirmed by correlation analysis. the positive correlation of " $\mathrm{Y}$ " for " $\mathrm{X} 1$ " and " $\mathrm{X} 2$ " is generally natural and high -0.97 and does not require additional comments. The causal relationship between the growth of pharmaceutical products in the case of an increase in the wage Fund and marketing, organizational and technological costs follows from experience, is noticeable empirically, and the high correlation coefficient demonstrates the significant role of this factor.

The negative relationship between production volumes and the share of producers participating in NIR (and the correlation coefficient is also high, -0.87 , can be interpreted in several other ways: 
- research and development costs contributed to the diversion of working capital through a production or marketing program;

- research and development costs have replaced the costs of innovation and productivity, which have a positive impact on production;

- patents as the results of joint research and development are registered abroad, where the corresponding production is carried out, without the introduction of appropriate production technologies in Russia.

To confirm our assumption about the positive influence of two factors $\mathrm{x} 1, \mathrm{x} 2$ and the negative influence of factor $\mathrm{X} 3$, a regression model was constructed. The analysis of environmental factors that affect the development of pharmaceutical production in the resulting regression model allowed us to identify trends in key factors and describe the real model in the form of a formula:

where:

$$
\mathrm{y}=55,0405+0,0097 \times 2+6,6404 \times 3-4,3029 \times 3
$$

$\mathrm{x} 1$ - expenses for technological, marketing and organizational innovations, mln rubles;

x2 - monthly average employees compensation within the organizations occupied in the production of pharmaceutical products, one thousand rubles;

$\mathrm{x} 3$ - share of the pharmaceutical organizations participating in joint (including foreign) projects on R\&D, $\%$.

As the scenario determines a strategy of the industry where external environment factors change, the realistic scenario is constructed in this research. Values of factors of the external environment according to the realistic scenario were predicted by means of extrapolation, proceeding from the assumption of consistency of the tendencies of a stage of a macroeconomic cycle designated below, and the purposes of the state industrial policy and objectives of the state industrial policy.

The approximation coefficient $\left(\mathrm{R}^{2}\right)$ became a criterion of the choice of the result. The factor for $\mathrm{x} 1, \mathrm{x} 2$, $\mathrm{x} 3$ trend lines is constructed by means of a polynomial method since it is having a higher value of the coefficient of approximation in comparison with a logarithmic and linear method (Fig. 3, Fig. 4, Fig. 5).

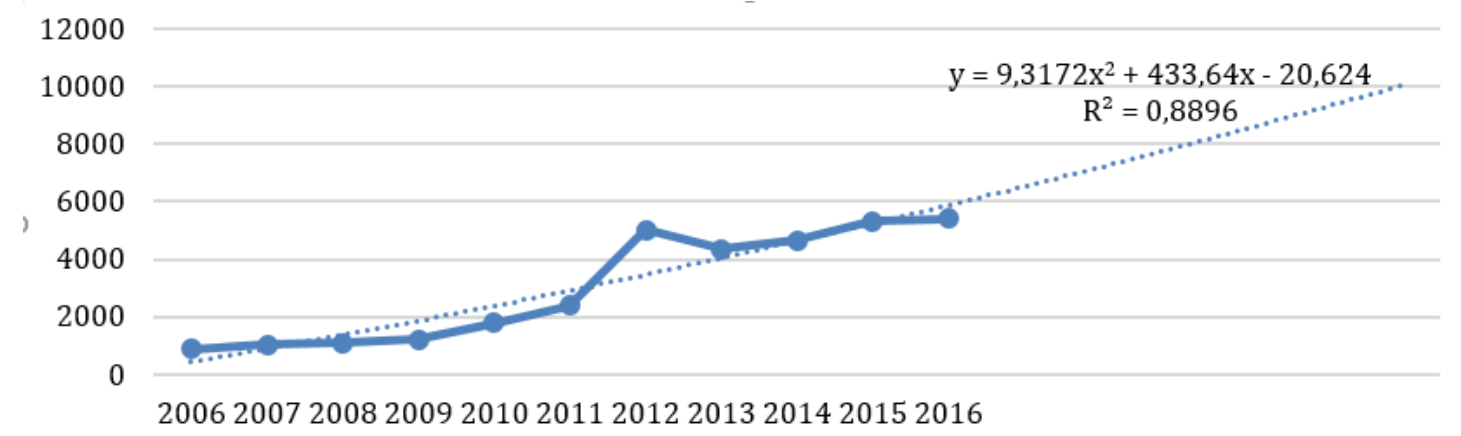

Fig. 3. Creation of a polynomial trend line for a factor of "Costs for technological, marketing and organizational innovations of the pharmaceutical entities and organizations (mln rubles)" 


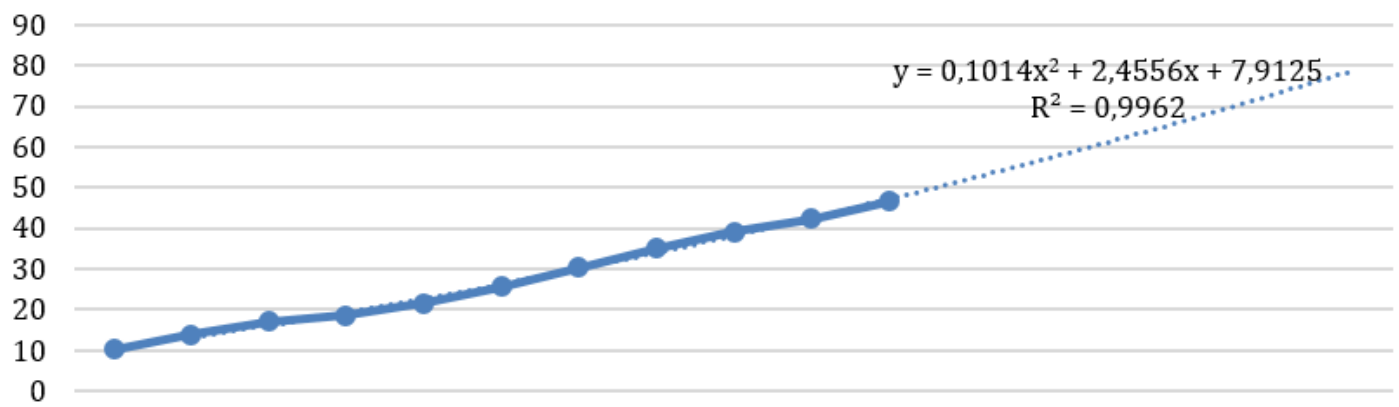

20062007200820092010201120122013201420152016

Fig. 4. Creation of a polynomial trend line for a factor "An average nominal wage of employees of the pharmaceutical organizations" (thousand rubles)

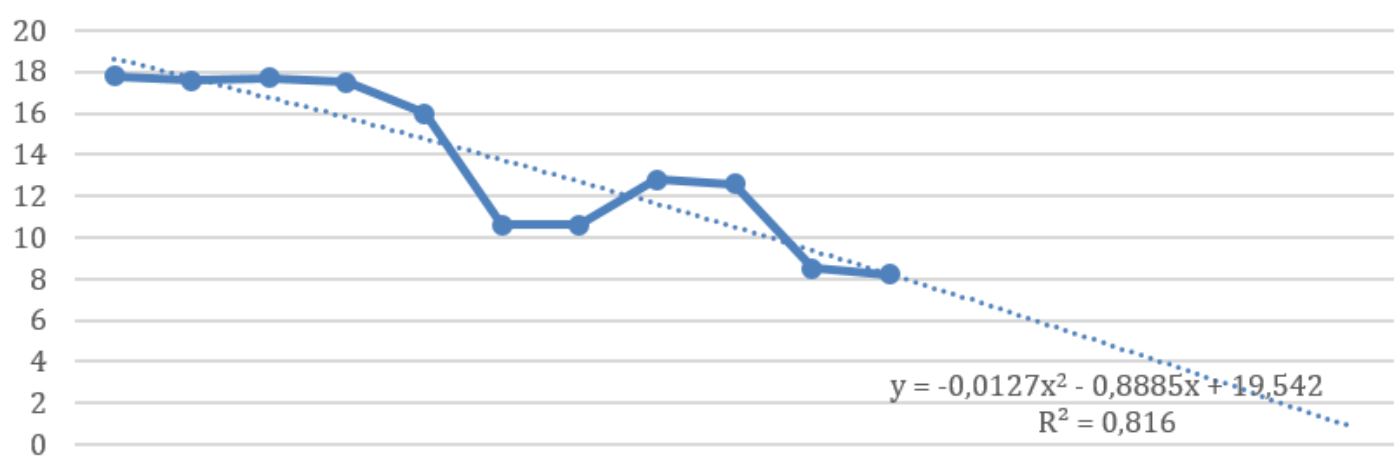

20062007200820092010201120122013201420152016

Fig. 5. Creation of a polynomial trend line for a factor "Specific weight of the pharmaceutical organizations participating in joint projects on accomplishment of research and development"(\%)

The results of calculations of forecast values of strategic factors received by means of creations of trend lines are provided in Table 2 (Gorodnikova et.al 2017), (Healthcare in Russia 2017).

Table 2. The forecast of values of the strategic factors influencing production volume of medicines

\begin{tabular}{|c|c|c|c|c|}
\hline S.No & Forecast & $\begin{array}{c}\text { Costs for technological, } \\
\text { marketing and organizational } \\
\text { innovations, mln rub. (x1) }\end{array}$ & $\begin{array}{c}\text { An average monthly nominal } \\
\text { accrued payroll in an industry, } \\
\text { thousand rub. } \\
(\mathrm{x} 2)\end{array}$ & $\begin{array}{c}\text { Share of pharmaceutical entities } \\
\text { and organizations participating in } \\
\text { joint (including foreign) projects } \\
\text { on accomplishment of research } \\
\text { and development, } \% \\
(\mathrm{x} 3)\end{array}$ \\
\hline 1 & 2019 & 7187,900 & 56,972 & 5,84 \\
\hline 2 & 2020 & 7872,600 & 62,165 & 4,61 \\
\hline 3 & 2021 & 8575,900 & 67,562 & 3,36 \\
\hline 4 & 2022 & 9297,800 & 73,161 & 2,07 \\
\hline
\end{tabular}

Source: Russian Federal State Statistics Service 
Determination of the production of medicines in the major pharmacotherapeutic groups according to the realistic scenario was performed by the substitution of the received values of key factors in the real (regression) model (1). The obtained data are provided in Fig. 6.

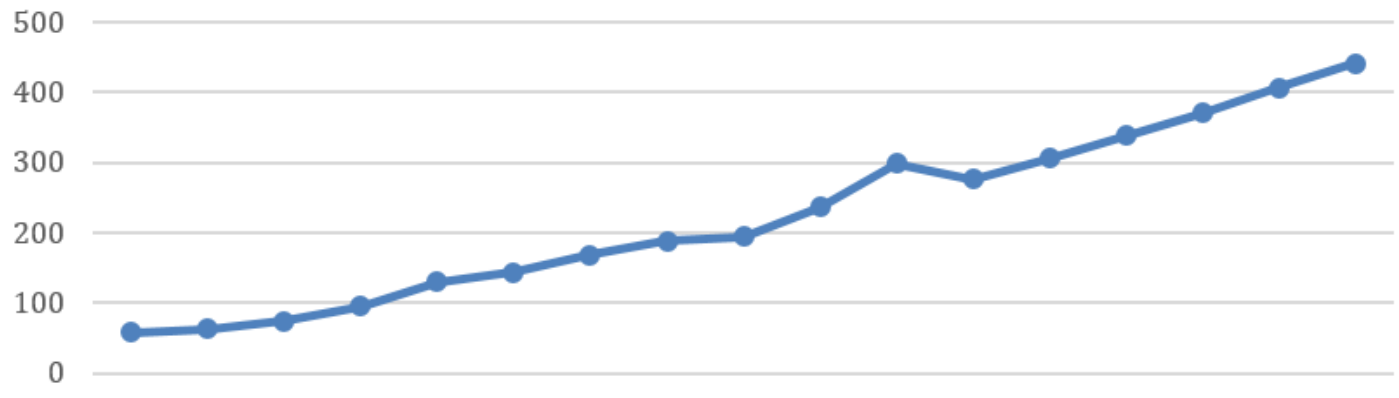

20062007200820092010201120122013201420152016201720182019202020212022

Fig. 6. The realistic production forecast of medicines at the major pharmacotherapeutic groups (billion rubles) taking into account the influence of the revealed actual strategic factors

According to the obtained results, it is possible to draw a conclusion that if the tendency of development of the considered indicators will continue, then by 2022, the production volume of medicines in the major pharmacotherapeutic groups increases to 441 billion rubles. In spite of this fact, data of the forecast of specific weight of the pharmaceutical organizations participating in joint projects on performance of a scientific research show negative dynamics.

If the tendency remains the same, then by 2022 , the share of the organizations participating in joint R\&D projects decreases to $2,07 \%$. One more revealed factor, which is positively influencing pharmaceutical production, is a compensation level of workers. In final calculations values, the growth of this indicator is observed. Costs for technological, marketing, organizational innovations also grow that demonstrates creation of conditions for innovative development of an industry.

\section{Conclusions}

The tools of an initial assessment of the external environment factors influencing the development of pharmaceutical production in Russia are tested. The actual external factors influencing the development of the pharmaceutical entities are revealed. The realistic production forecast by major pharmaceutical groups, considering the influence of the revealed actual strategic factors, is constructed.

The interrelation between macrofactors of the Russian pharmaceutical industry development and the amounts of its production are confirmed and measured in the research. This research is a reason for discussion and further studying of development of reasonable recommendations in order to change or refine the state industrial policy. The directions of further researches are connected with deeper studying of causes of relationships between production volumes and macrofactors, as well as with the assessment of time distribution of macroeconomic consequences of purposeful impact on a size of the considered factors. 


\section{ENTREPRENEURSHIP AND SUSTAINABILITY ISSUES}

ISSN 2345-0282 (online) http://jssidoi.org/jesi/

2020 Volume 7 Number 4 (June)

http://doi.org/10.9770/jesi.2020.7.4(29)

\section{References}

Smolina, E.S., Kuzaeva, E.Y., Kazakova, O.B., Kuzminykh, N.A. Analysis of Innovative Activity of Russian Oil and Gas Companies in the Context of World Experience. Lecture Notes in Networks and Systems. Volume 84, 2020, Pages 281-289.

Brem, A., Nylund, P.A., Schuster, G. Innovation and de facto standardization: The influence of dominant design on innovative performance, radical innovation, and process innovation. Technovation Volume 50-51, 1 April 2016, Pages 79-88.

Voloshin, A.V, Suslova, J.J., Batrayeva, E.A., Baguzova, L.V. Current state, tendencies and peculiarities of development in higher education: The case of Russia. European Research Studies Journal. Volume 21, Issue 4, 2018, Pages 502-511.

Kayl, I.I., Epinina, V.S., Zudina, E.V., Pliev, G.A., Samsonova, M.V. GR-management as a modern mechanism of increasing the efficiency of interaction of educational organizations with public authorities: Foreign and domestic experience .Quality - Access to Success Volume 19, Issue S2, 1 July 2018, Pages 93-97.

Bogoviz A.B., Tretyakova, O.G., Zakharov, M.Y. Globalization of Education in the Conditions of Formation of the Global Knowledge Economy: Regularities and Tendencies. Lecture Notes in Networks and Systems Volume 73, 2020, Pages 993-1000.

Bogoviz, A.V., Lobova, S.V., Ragulina, J.V., Vypryazhkina, I.B., Boldyreva, I.N. Educational incentives for creating high-performance jobs. Quality - Access to Success, Volume 19, Issue S2, 2018, Pages 57-61.

Bogoviz A.V., Gimelshteyn A.V., Shvakov E.E., Maslova E.V., Kolosova A.A. Digitalization of the Russian education system: Opportunities and perspectives. Quality - Access to Success, Volume 19, Issues S2, 2018, Pages 27-32.

Chashchin, V.V., Popkova, E.G., Zabaznova, T.A., Ostrovskaya, V.N. Application of staff marketing in educational services market. Middle East Journal of Scientific Research, Volume 16, Issues 6, 2013, Pages 865-870.

Crespi, G., Katz, J., Olivari, J. Innovation, natural resource-based activities and growth in emerging economies: The formation and role of knowledge-intensive service firms. Innovation and Development, Volume 8, Issue 2018, Pages 79-101.

Atatsi, E.A., Stoffers, J., Kil, A. Factors affecting employee performance: a systematic literature review. Journal of Advances in Management Research. Volume 16, Issue 3, 15 July 2019, Pages 329-351.

Barney, J.B., Wright, P.M. On becoming a strategic partner: The role of human resources in gaining competitive advantage. Human Resource Management, Volume 37, Issue 1, 1998, Pages 31-46.

Gorodnikova, N. 2017. Indicators of innovation statistical yearbook Higher School of Economics. Moscow: Published Higher School of Economics.

Healthcare in Russia 2017. Federal State Statistics Service. [E-Reader Version]. Retrieved from http://www.gks.ru/free_doc/doc_2017/zdrav17.pdf

OECD 2015. Health at a Glance 2015: OECD Indicators. Paris: OECD Publishing.

Pharmaceutical spending 2015. [E-Reader Version]. Retrieved from http https://data.oecd.org/healthres/pharmaceutical-spending.htm

IFPMA. The Pharmaceutical Industry and Global Health Facts and Figures. 2017. [E-Reader Version]. Retrieved from https://www.ifpma.org/wp-content/uploads/2017/02/IFPMA-Facts-And-Figures-2017.pdf

Ding M., Eliashberg J., Stremersch S. 2014. Innovation and marketing in the pharmaceutical industry. Emerging Practices, Research, and Policies. New York: Spring Science. p. 57- 98

DiMasi J. A., Hansen R. W., Grabowski H. G. 2003 The price of innovation: new estimates of drug development costs. Journal of Health Economics. Volume 22, Issue 2, Pages 151-185.

DiMasi J. A., Grabowski H. G., Hansen R. W. 2016 Innovation in the pharmaceutical industry: new estimates of R\&D costs. Journal of Health Economics, Volume 47, Pages 20-33. 


\section{ENTREPRENEURSHIP AND SUSTAINABILITY ISSUES}

ISSN 2345-0282 (online) http://jssidoi.org/jesi/

2020 Volume 7 Number 4 (June)

http://doi.org/10.9770/jesi.2020.7.4(29)

Global R\&D Funding Forecast 2016. R\&D Magazine. [E-Reader Version]. Retrieved from https://www.iriweb.org/sites/default/files/2016GlobalRDFundingForecast.pdf

Niu, J.-Z., Yang, D.-S., Xu, M.-D Brief introduction of the authorized generic drug in the USA and its application in the availability of reference listed drug. Chinese Journal of New Drugs. Volume 28, Issue 5, 15 March 2019, Pages 604-607.

The Global Competitiveness Report 2018. [E-Reader Version]. Retrieved from http://reports.weforum.org/global-competitiveness-report$\underline{2018}$

Natalia Leonidovna BORSCHEVA

ORCID ID: 0000-0001-7632-7155

Yulia Vyacheslavovna FEDOROVA

ORCID ID: 0000-0003-2663-6536

Marina Ivanovna GLUKHOVA

ORCID ID: 000-0003-0142-617X

Guzal Ilgizovna ISLAMOVA

ORCID ID: 0000-0001-7966-4392

Register for an ORCID ID:

https://orcid.org/register

Copyright (C) 2020 by author(s) and VsI Entrepreneurship and Sustainability Center

This work is licensed under the Creative Commons Attribution International License (CC BY).

http://creativecommons.org/licenses/by/4.0/

cC) (i) Open Access 